\begin{tabular}{|c|c|}
\hline MBR & Management and Business Review \\
\hline $\begin{array}{c}\text { MANAGEMENT \& } \\
\text { BUSINESS REVIEW } \\
\end{array}$ & $\begin{array}{l}\text { Available at http://ejournal.unikama.ac.id/index.php/mbr } \\
\text { ISSN: } 2541-5808 \text { (online) }\end{array}$ \\
\hline
\end{tabular}

\title{
Early Warning System Kondisi Financial pada Industri Manufaktur di BEI
}

\section{Sabar}

Department of Management, Economic and Business Faculty, Universitas Airlangga,

Indonesia

e-mail: sabar@prodes.its.ac.id

Article Info:

Receive : Juli, 2018

Revised : Oktober, 2018

Accepted : Nopember 2018

Published : December 2018

DOI : : 10.21067/mbr.v2i2.4689

Copyright: Management and

Business Review

Keywords :

distress, intensiveness,

indebtedness
Abstract: The problem of predicting risk is still a specific problem that requires attention in the investment sector. Previous research has found that there is a kind of early warning system (EWS) for investors that can be used as a reference for prudence. This study provides EWS for investors who are engaged in the processing industry that goes public on the IDX. This study seeks to distinguish companies in the category of financial distress and not financial distress. The financial variables used are included in the short term liquidity, long term solvency, profitability, productivity, indebtedness, investment intention, leverage, return on investment, equity and EVA. The test results show that there are 14 financial ratios that have differences between the financial ratios in the category of non-financial distress and financial distress companies.

Abstrak: Problemasi memprediksi risiko masih menjadi permasalahan spesifik yang memerlukan perhatian dalam bidang investasi. Penelitian sebelumnya menghasilkan temuan bahwa ada semacam bahwa early warning system (EWS) bagi investor dapat dijadikan acuan untuk kehatihatian. Penelitian ini memberikan EWS bagi investor yang menekuni industry pengolahan yang go public di BEI. Penelitian ini berupaya membedakan perusahaan dalam kategori kesulitan keuangan dan tidak kesulitan keuangan. Variabel keuangan yang digunakan tergabung dalam kelompok short term liquidity, long term solvency, profitability, productivity, indebtedness, investment intensiveness, leverage, return on investment, equity dan EVA. Hasil uji terdapat 14 rasio keuangan yang memiliki perbedaan antara rasio keuangan pada kategori perusahaan non-financial distress dan financial distress. 


\section{Pendahuluan}

Pada prinsipnya, biaya pendanaan yang lebih tinggi yang mengikuti distress dalam industri dapat mengurangi investasi dengan mempengaruhi kemampuan pesaing untuk memperoleh dana yang cukup (Garcia-Appendini, 2018). Namun, pesaing yang menghadapi kesulitan keuangan dapat memfasilitasi predasi oleh perusahaan lain dalam industri tersebut, yang dapat mengeksploitasi pesaingnya. kelemahan dan meningkatkan investasi untuk mendapatkan pangsa pasar yang lebih tinggi (Opler \& Titman, 1994). Terdapat empat indikator atau sumber informasi financial distress, yaitu analisis arus kas, analisis strategi perusahaan, analisis laporan keuangan dan informasi eksternal. Dari keempat sumber informasi tersebut yang sangat mungkin dijadikan alat untuk menilai kinerja dan mengetahui indikasi terjadinya financial distress adalah analisis laporan keuangan yang diterbitkan perusahaan. Hal tersebut seiring dengan pendapat Brigham dan Gapenski dalam (Dempsey et al., 2015) yang menyatakan: "Financial statements report both on firm's position at a point in time and on its operations over some past period. However, the real value of financial statements lies in the fact that they can be used to help predict the firm's future earnings and dividends. From an investor's standpoint, predicting the future is what financial statement analysis is all about..."

Penggunaan laporan keuangan sebagai sumber informasi untuk prediksi financial distress dapat dilakukan dengan univariate analysis atau multivariate analysis. Model tersebut melibatkan variabel bebas dan variabel tergantung dan sebagai variabel bebas adalah rasio keuangan yang diperkirakan mempengaruhi financial distress perusahaan, sedangkan sebagai variabel terikat adalah prediksi terjadinya financial distress. Van Horne \& Wachowicz (2005) mengatakan: "To evaluate the financial condition and performance of the firm, the analyst need to perform 'checkups' on various aspects of a firm's financial health. A tool frequently used during these checkups is a financial ratio, or index, which related two pieces of financial data by dividing one quantity by other." Analisis yang berdasarkan rasio keuangan akan diketahui kinerja keuangan, sehingga dapat pula diketahui pula kondisi perusahaan.

Laporan keuangan merupakan salah satu bentuk pertanggungjawaban manajemen atas kinerja keuangan perusahaan. Cara umum yang dipakai untuk menganalisis laporan keuangan adalah pengunaan rasio-rasio. Kesulitan dalam pengambilan keputusan dengan menggunakan rasio-rasio keuangan adalah rasiorasio tersebut cukup banyak dan bervariasi, disamping hasil perhitungan yang didapat bersifat individual, dan tidak dapat langsung digunakan untuk mengambil keputusan ekonomi. Jadi dengan kata lain, rasio-rasio keuangan yang dapat berperan sebagai indikator-indikator pemberi sinyal financial distress, tidak dapat 
berpengaruh sendiri-sendiri terhadap prediksi financial distress. Walaupun demikian dari sekian banyak rasio keuangan, belum dapat dipastikan rasio-rasio mana saja yang dominan untuk mempengaruhi kondisi financial distress perusahaan.

Perusahaan-perusahaan yang terdaftar di Bursa Efek Jakarta yang secara teknis sudah tidak dapat dipertahankan lagi, perlu secara dini diketahui oleh investor. Penelitian yang menghasilkan suatu model untuk tindakan preventif sebagai sistem peringatan dini (early warning sistem), diharapkan dapat dipakai perusahaan untuk mengantisipasi kemungkinan memburuknya kondisi keuangan perusahaan yang pada akhirnya berakibat pada kebangkrutan.

Penelitian ini dimaksudkan untuk memberikan informasi kepada investor bahwa financial distress dapat diprediksi jauh-jauh hari sebelumnya dengan menggunakan analisis diskriminan. Oleh karena itu penelitian dilakukan tentang "Early Warning System Financial Pada Industri Manufaktur Di BEI" Berdasarkan latar belakang yang telah dikemukakan di atas, makatujuan penelitian adalah:

1. Menganalisis rasio short term liquidity, long term solvency, profitability, productivity, indebtedness, investment intensiveness, leverage, return on investment, equity dan EVA secara simultan memiliki kontribusi dalam mengelompokkan perusahaan kategori financial distress dan non financial distress industri manufaktur di BEI.

2. Menguji perbedaan rasio keuangan short term liquidity, long term solvency, profitability, productivity, indebtedness, investment intensiveness, leverage, return on investment, equity dan EVA antara perusahaan kategori financial distress dan non financial distress pada industri manufaktur di BEI.

\section{Method}

\section{Definisi Operasional Variabel}

Definisi operasional variabel yang digunakan dalam penelitian ini adalah: Variabel tergantung $(Z)$, dengan pengelompokan mengacu pada Ross et al., sebagai berikut: Perusahaan dalam kategori financial distress adalah perusahaan dengan ekuitas negatif (kelompok 1). Perusahaan dalam kategori non financial distress adalah perusahaan dengan ekuitas positif (kelompok 2).

Variabel bebas $(\mathrm{X})$, yaitu yang terdiri dari rasio-rasio keuangan, rasio keuangan diambil dari laporan keuangan perusahaan berupa neraca dan laporan laba rugi perusahaan 31 Desember tahun 2015-2017, yang terdiri dari X1= Current Assets to Current Liabilities, X2 = Current Assets to Total Liabilities, X3=Earning Before Taxes to Sales, X4= Operating Income to Earning Before Taxes, X5= Gross Profit to Sales, $X 6=$ Net Income to Sales, X7= Sales to Account Receivable, X8=Current Assets to Total Assets, X9= Inventory to Sales, X10= Sales to Total Assets, X11= Working Capital to Total 
Assets, X12= Total liabilities to Current Assets, X13= Operating Income to Total Liabilities, X14 $=$ Current Liabilities to Total Assets, X15 $=$ Sales to Fixed Assets, X16= Current Assets to Sales, X17= Total Liabilities to Total Assets, X18= Net Income to Fixed Assets, X19= Earning Before Taxes to Total Assets, X20= Net Income to Total Assets, $\mathrm{X} 21=$ Sales to Current Liabilities,, $\mathrm{X} 22$ = return onequity.

\section{Teknik Pengambilan Sampel}

Populasi penelitian adalah seluruh saham yang tercatat di BEJ. Sampel diambil perusahaan-perusahaan manufaktur yang listing di BEJ sebesar 96 perusahaan dari 146 perusahaan. Alasan pengambilan jumlah sampel semata- mata dibatasi oleh ketersediaan data. Pengkategorian sampel dalam kategori financial distress dan non financial distress mengacu pada Hillier et al. (2013) bahwa perusahaan dalam kesulitan keuangan ditandai dengan ekuitas negatif. Terdapat 15 perusahaan yang tergolong dalam kategori financial distress dan 81 perusahaan tergolong dalam kategori non financial distress.

\section{Pengumpulan Data}

Data yang digunakan dalam penelitian ini merupakan data sekunder yang berupa laporan keuangan perusahaan yang diteliti yang berakhir pada 31 Desember 2017. Data dikumpulkan melalui dokumentasi di PRPM BEJ, PRPM BES, http: jsx.co.id.

\section{Teknik Analisis}

Analisis data dilakukan dengan melakukan langkah: menentukan kategori sampel financial distress dan non financial distress sebagai pengelompokan awal; menghitung rasio keuangan masing-masing perusahaan baik yang tergolong financial distress dan non financial distress; menguji asumsi dasar dalam analisis diskriminan, yaitu uji normal multivariate dan uji non multikolinieritas; mengolah data-data yang diperoleh dari perhitungan rasio keuangan dengan menggunakan program SPSS Versi 22. Data dihitung berdasarkan masing-masing tahun, sehingga diketahui pengelompokan yang terjadi dari masing-masing tahun.

Tahapan yang dilakukan menghitung nilai diskriminan untuk kelompok 1 perusahaan financial distress dan kelompok 2 perusahaan non financial distress dengan memasukkan nilai rata-rata rasio keuangan masing-masing variabel bebas dengan koefisien diskriminannya.

Pengujian hipotesis petama dilakukan dengan menggunakan hasil perhitungan chisquare berdasarkan analisis diskriminan direct method, yaitu untuk mengetahui pengaruh rasio-rasio keuangan perusahaan yang diteliti secara simultan terhadap pengelompokkan perusahaan pada kategori financial distress dan non-financial distress. Adapun pengujian hipotesis kedua dilakukan dengan menggunakan uji financial distress dan non financial distress yang diproses dengan menggunakan 
analisis diskriminan, yaitu dengan menggunakan $p$-value dari uji financial distress dan non financial distress.

\section{Hasil}

Analisis diskriminan adalah salah satu teknik pengelompokan yang digunakan dalam penelitian yang melibatkan pengukuran ganda. Secara teknis, pengelompokan dilakukan dengan cara memaksimumkan varians di antara kelompok (between) secara relatif terhadap varians di dalam kelompok (within), hubungan ini dinyatakan sebagai rasio varians antar kelompok dengan varians dalam kelompok.

Analisis diskriminan melibatkan kombinasi linier dari dua atau lebih variabel bebas (predictor) yang membedakan antar kelompok (group). Kombinasi linier untuk analisis diskriminan disebut sebagai fungsi diskriminan. Berdasarkan fungsi diskriminan yang terbentuk, maka setiap individu (case) yang diteliti dimasukkan sebagai anggota dalam salah satu kelompok dan tidak ada individu yang menjadi anggota lebih dari satu kelompok. Dalam fungsi diskriminan, variabel tak bebas merupakan kategori, sedangkan variabel bebas merupakan metrik.

Penelitian ini melibatkan 22 variabel bebas yang merupakan rasio-rasio keuangan. Input data pada program untuk tiap-tiap tahun 2015-2017 yang diperoleh dari pengolahan awal laporan keuangan perusahaan go public, dan nilai variabel tergantung yaitu kategori financial distress (dengan kode 1) dan kategori non-financial distress (dengan kode 2), untuk tiap-tiap tahun yang dianalisis.

Analisis diskriminan dapat digunakan untuk mengetahui pengaruh variabelvariabel bebas yang dianalisis secara simultan terhadap pengelompokan perusahaan dalam kategori financial distress dan non financial distress, yaitu dengan menggunakan analisis diskriminan direct method. Selain itu, analisis diskriminan juga dapat digunakan untuk mengetahui variabel-variabel (dari variabel bebas yang digunakan) yang secara signifikan membedakan perusahaan-perusahaan dalam kategori financial distress dan non-financial distress, yaitu dengan menggunakan analisis diskriminan stepwise method.

Terdapat perbedaan kondisi yang harus dipenuhi dalam mempersiapkan pengaplikasian analisis diskriminan, yang menjadi asumsi dasar dari analisis diskriminan. Asumsi dasar tersebut adalah: (1) multivariate normality of independent variable, dan (2) multicollinearity among independent variables. Pelanggaran terhadap asumsi dasar berupa multivariate normality of independent variable, dan multicollinearity among independent variables akan menyebabkan hasil penelitian tidak valid, sehingga akan meragukan jika akan digunakan sebagai estimator.

Pelanggaran pada multicollinearity among independent variables ditunjukkan oleh korelasi yang kuat antar variabel bebas, jika ini terjadi maka salah satu dari dua variabel yang mengandung multicollinearity tidak akan mampu diproses oleh komputer (variable remove). 
Salah satu asumsi kunci untuk mendapatkan fungsi diskriminan adalah multivariate normality dari variabel-variabel bebas. Analisis diskriminan sangat sensitive terhadap pelanggaran asumsi ini. Data dari variabel-variabel bebas yang tidak dapat memenuhi asumsi multivariate normality dapat menimbulkan masalah pada saat mengestimasikan fungsi diskriminan yang didapatkan.

Untuk itu, terlebih dahulu dilakukan pemeriksaan terhadap kondisi multivariate normality. Pemeriksaan dilakukan dengan melihat normal probability plot of regression standardized residual yang didapatkan dari analisis regresi linier dengan program SPSS 22, yang harus memiliki kecenderungan membentuk garis lurus. Pemeriksaan multivariate normality sebagai disajikan pada grafik yang memperlihatkan bahwa titik-titik plot memiliki kecenderungan membentuk garis lurus, sehingga dapat disimpulkan bahwa data variabel- variabel bebas telah memenuhi asumsi multivariate normality.

Normal P-P Plot of Regression Standardized Residual

Dependent Variable: Z

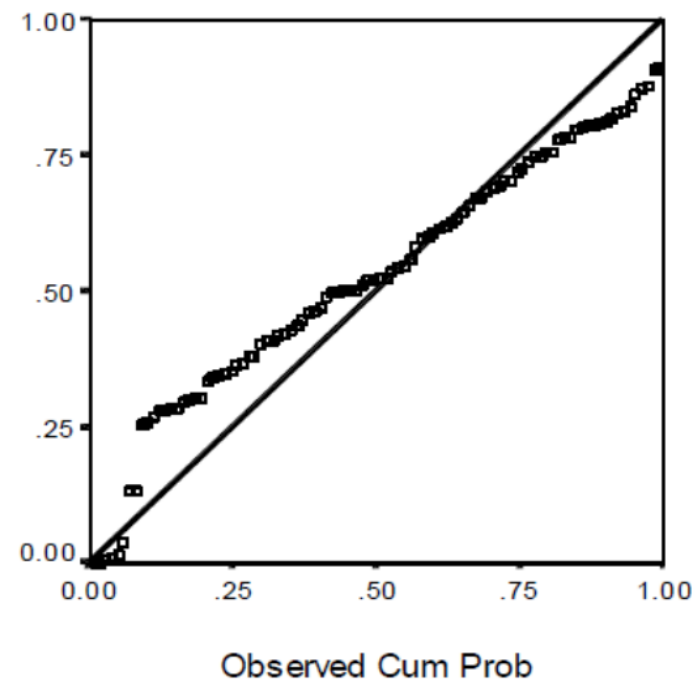

Gambar 1. Grafik Plot Regresi Untuk Pemerikasaan Multivariate Normality

\section{Multicollinearity Among Independent Variabel}

Asumsi kunci yang lain, untuk mendapatkan fungsi diskriminan adalah bahwa dua atau lebih dari veriabel-veriabel bebas memiliki korelasi yang tinggi sehingga suatu variabel bebas dapat diprediksi atau dijelaskan oleh variabel bebas lainnya, yang akan mempengaruhi keseluruhan penjelasan dalam analisis. Oleh karena itu, terlebih dahulu dilakukan pemeriksaan terhadap kondisi multicollinearity. Pemeriksaan dilakukan dengan melihat matriks korelasi yang didapat dari analisis koefisien korelasi melalui program SPSS.10.01. terhadap seluruh variabel bebas, dengan ketentuan koefisien korelasi tidak boleh melebihi \pm 0,70 (Gujarati, 2012. Pemeriksaan multicollinearity untuk tahun 2017. Matrik tersebut 
memperlihatkan bahwa koefisien korelasi yang didapat besarnya tidak melebihi \pm 0,70, sehingga dapat disimpulkan bahwa data variabel-variabel bebas untuk tahun 2017 telah memenuhi asumsi non multicollinearity.

\section{Hasil Perhitungan Direct Method}

Hasil perhitungan direct method menunjukkan bahwa dari 96 kasus yang diteliti ternyata semuanya valid untuk diproses. Ringkasan hasil perhitungan pada tabel 1.

Tabel 1. Ringkasan Hasil Analisis Diskriminan Direct Method

\begin{tabular}{llr}
\hline Tabel Eigenvalues & Canonical & 0,868 \\
& Correlation & \\
Tabel Wilks Lamda & Chi Square & 116,346 \\
& Sign. & 0,000 \\
Function & Kategori non fD & $-0,745$ \\
at group centeroid & Kategori FD & 4,024 \\
Tingkat Keakuratan & Original Grouped & $97,9 \%$ \\
& Cross Validated & $94,8 \%$ \\
& Grouped & \\
\hline
\end{tabular}

Pengelompokan 96 perusahaan dengan menggunakan rasio keuangan perusahaan sebagai variabel bebas, menunjukkan bahwa secara simultan menghasilkan fungsi diskriminan yang dapat dituliskan sebagai:

$$
\begin{aligned}
& Z=0,676 X 1+0,240 X 2-0,001 X 3-0,038 X 4-0,454 X 5-0,440 X 6-0,134 X 7-0,288 X 8+ \\
& 0,299 \times 9+0,800 \times 10-0,056 X 11-0,288 \times 12+-0,318 X 13-0,632 X 14+0,001 X 15- \\
& 0.250 \times 16+ \\
& \text { 1,394X17 + 0,003X18. - 0,675X19+0,868X20 - 0,813X21+0,313X22. }
\end{aligned}
$$

Nilai canonical correlation tabel eigenvalues yang diperoleh adalah 0,920 yang jika dikuadratkan menjadi 0,8464. Hal ini berarti 84,64\% dari varians dapat dijelaskan oleh fungsi diskriminan yang terbentuk. Nilai chi-square (pada lampiran 4b) tabel Wilks'Lamda yang diperoleh adalah sebesar 155,836 dengan tingkat signifikansi sebesar 0,000 dan lebih kecil dari level of significant yang digunakan sebesar 0,05. Hal ini mengindikasikan perbedaan yang signifikan antara kedua kelompok pada fungsi diskriminan yang terbentuk, di mana kondisi keuangan perusahaan yang berada dalam kategori financial distress berbeda secara nyata dengan kondisi keuangan perusahaan yang termasuk kategori non-financial distress. Melalui fungsi diskriminan yang diperoleh, maka tiap-tiap perusahaan yang diteliti akan memiliki skor yang digunakan sebagai dasar pengelompokan, masuk dalam kategori financial distress atau non-financial distress. Batas skor untuk kategori financial distress dan non- 
financial distress disebut sebagai cutting score $\left(\mathrm{Z}_{\mathrm{cu}}\right)$ yang dapat dihitung dengan memperhatikan angka-angka yang terdapat dalam lampiran 4a tabel function at group centeroids. Tabel tersebut memperlihatkan angka 5,411 untuk kategori financial distress dan -1,002 untuk kategori non financial distress. Perhitungan cutting score adalah sebagai berikut :

$$
Z_{c u}=\frac{(15 x-0.74 \times 0.05)+(81 \times 4.024 \times 0.05)}{15+81}=1.639
$$

Jika discriminant score yang diperoleh perusahaan lebih kecil dari 1,639 maka perusahaan tersebut masuk dalam kategori non financial distress dan jika discriminant score yang diperoleh perusahaan lebih besar dari 1,639 maka perusahaan tersebut masuk dalam kategori financial distress. Hasil perhitungan untuk tiap perusahaan nampak pada casewise statistics for the original data.

Tingkat keakuratan dari fungsi diskriminan yang diperoleh dalam melakukan prediksi pengelompokan perusahaan pada kategori financial distress dan non financial distress untuk original grouped adalah 97,9\%. Ini berarti bahwa pengelompokan hasil prediksi tidak semuanya sesuai dengan pengelompokan pada kondisi aktual, terdapat 1 perusahaan yang tidak tepat diklasifikasikan (misclassified) oleh fungsi diskriminan yang terbentuk, perusahaan:

1. PT Indomobil Sukses Internasional, Tbk pada bagian predicted group termasuk dalam kategori non-financial distress (kategori 2), sedangkan pada bagian actual group termasuk dalam kategori financial distress. Prediksi pengelompokan PT Indomobil Sukses Internasional, Tbk pada kategori financial distress disebabkan oleh skor diskriminan yang diperoleh adalah $1,003(<1,639)$.

2 PT Miwon Indonesia, Tbk pada bagian predicted group termasuk dalam kategori non-financial distress (kode 2), sedangkan pada bagian actual group termasuk dalam kategori financial distress (kategori 1). Prediksi pengelompokan PT Miwon, Tbk pada kategori non-financial distress disebabkan oleh skor diskriminan yang diperoleh adalah $-0,844(<1,639)$.

Untuk menghindari pendapat bahwa klasifikasi dengan fungsi diskriminan yang didapat terlalu optimis dan tidak memperhitungkan berbagai bias yang mungkin terjadi, maka digunakan metode leave-one-out classification untuk melakukan cross validation. Ternyata tingkat keakuratan fungsi diskriminan yang diperoleh untuk cross-validated grouped adalah $94,8 \%$ yang masih dapat diartikan bahwa keakuratannya tinggi. 


\section{Pembahasan}

Hasil pengolahan data variabel-variabel yang diteliti melalui analisis diskriminan direct method maupun stepwise method, dijadikan dasar dalam menguji hipotesis yang telah diajukan, untuk menjawab permasalahan dan memperoleh tujuan yang ingin dicapai dalam melakukan penelitian ini. Hipotesis pertama dalam penelitian ini menduga rasio-rasio keuangan perusahaan secara simultan dapat digunakan untuk mengelompokkan perusahaan dalam kategori non financial distress dan financial distress dengan menggunakan analisis diskriminan.

Untuk membuktikan hipotesis tersebut, dilakukan analisis diskriminan dengan metode direct untuk masing-masing tahun sebagai berikut:

Pengolahan data rasio keuangan tahun 2015 dengan menggunakan direct method, menghasilkan nilai chi-square sebesar 120,741. Nilai chi-square. tabel dengan variabel bebas sebanyak 22 dan signifikansi 5\% adalah sebesar 26,2962. Terlihat bahwa nilai chi-square hasil pengolahan data ternyata lebih besar dari nilai chisquare tabel, sehingga dapat disimpulkan bahwa hipotesis nul (H0) ditolak. Dengan demikian H1 diterima, bahwa terbukti rasio-rasio keuangan perusahaan secara simultan dapat digunakan untuk mengelompokkan perusahaan-perusahaan go public dalam kategori non financial distress dan financial distress dengan menggunakan analisis diskriminan pada tahun 2015.

Pengolahan data rasio keuangan tahun 2016 dengan menggunakan direct method, menghsailkan nilai chi-square sebesar 155,836. Nilai chi-square tabel dengan variabel bebas sebanyak 22 dan signifikansi 5\% (X) adalah sebesar 26,2962. Terlihat bahwa nilai Nilai chi-square hasil pengolahan data ternyata lebih besar dari nilai Nilai chi-square tabel, sehingga dapat disimpulkan bahwa hipotesis nul (H0) ditolak. Dengan demikian H1 diterima, bahwa terbukti rasio-rasio keuangan perusahaan secara simultasn dapat digunakan untuk mengelompokkan perusahaan-perusahaan go public dalam kategori non-financial distress dan financial distress.

Pengolahan data rasio keuangan tahun 2017 dengan menggunakan direct method, menghsailkan nilai chi-square sebesar 116,346. Nilai chi-square tabel dengan variabel bebas sebanyak 22 dan signifikansi 5\% (X) adalah sebesar 26,2962. Terlihat bahwa nilai Nilai chi-square hasil pengolahan data ternyata lebih besar dari nilai Nilai chi-square tabel, sehingga dapat disimpulkan bahwa hipotesisnul (H0) ditolak. Dengan demikian H1 diterima, bahwa terbukti rasio-rasio keuangan perusahaan secara simultasn dapat digunakan untuk mengelompokkan perusahaan-perusahaan go public dalam kategori non-financial distress dan financial distress. 
Tabel 2. Uji F Sinifikansi Variabel Diskriminan

\begin{tabular}{|c|c|c|c|c|c|}
\hline Variabel & $\begin{array}{c}\text { Wilks' } \\
\text { Lambda }\end{array}$ & F & $\mathrm{Df}_{1}$ & $\mathrm{Df}_{2}$ & Sig. \\
\hline $\mathrm{X}_{1}$ & .862 & 14.989 & 1 & 94 & .000 \\
\hline$X_{2}$ & .900 & 10.433 & 1 & 94 & .002 \\
\hline$X_{3}$ & .608 & 60.606 & 1 & 94 & .000 \\
\hline $\mathrm{X}_{4}$ & .996 & .361 & 1 & 94 & .549 \\
\hline$X_{5}$ & .827 & 19.696 & 1 & 94 & .000 \\
\hline$X_{6}$ & .689 & 42.356 & 1 & 94 & .000 \\
\hline$X_{7}$ & .996 & .352 & 1 & 94 & .555 \\
\hline $\mathrm{X}_{8}$ & .955 & 4.469 & 1 & 94 & .037 \\
\hline$X_{9}$ & .992 & .776 & 1 & 94 & .381 \\
\hline$X_{10}$ & .997 & .309 & 1 & 94 & .579 \\
\hline$X_{11}$ & .981 & 1.853 & 1 & 94 & .177 \\
\hline$X_{12}$ & .578 & 68.629 & 1 & 94 & .000 \\
\hline $\mathrm{X}_{13}$ & .923 & 7.840 & 1 & 94 & .006 \\
\hline$X_{14}$ & .437 & 121.303 & 1 & 94 & .000 \\
\hline $\mathrm{X}_{15}$ & .995 & .448 & 1 & 94 & .505 \\
\hline $\mathrm{X}_{16}$ & .985 & 1.432 & 1 & 94 & .234 \\
\hline $\mathrm{X}_{17}$ & .379 & 153.706 & 1 & 94 & .000 \\
\hline $\mathrm{X}_{18}$ & .935 & 6.573 & 1 & 94 & .012 \\
\hline $\mathrm{X}_{19}$ & .562 & 73.292 & 1 & 94 & .000 \\
\hline$X_{20}$ & .646 & 51.587 & 1 & 94 & .000 \\
\hline$X_{21}$ & .838 & 18.159 & 1 & 94 & .000 \\
\hline$X_{22}$ & .986 & 1.302 & 1 & 94 & .257 \\
\hline
\end{tabular}

Hipotesis kedua dalam penelitian ini menduga terdapat perbedaan rasio keuangan rasio-rasio keuangan perusahaan (short term liquidity, long term solvency, profitability, productivity, indebtednees, invesment intensiveness, leverage, return on investment dan equity), antara kelompok perusahaan dalam kategori non-financial distress dan financial distress. Hipotesis tersebut secara statistik dituliskan sebagai berikut: 
H0: P-value $>0,05$ dan H1 : P-value $<=0,05$

Hipotesis tersebut diujikan untuk masing-masing variabel bebas yang merupakan rasio keuangan perusahaan (short term liquidity, long term solvency, profitability, productivity, indebtednees, invesment intensiveness, leverage, return on investment dan equity) dengan menggunakan uji $\mathrm{F}$, yang diproses dengan menggunakan analisis diskriminan. Hasil uji untuk sebagai mana disajikan pada tabeld di atas. Terdapat 14 rasio keuangan yang memiliki perbedaan antara rasio keuangan pada kategori perusahaan non-financial distress dan financial distress.

Untuk keempatbelas rasio keuangan tersebut berarti menolak H0 dan menerima H1, sedangkan pada 8 rasio keuangan lainnya menolak $\mathrm{H} 1$ dan menerima $\mathrm{H} 0$ dapat diartikan bahwa rasio keuangan tersebut tidak memiliki perbedaan antara perusahaan dalam kategori non-financial distress dan financial distress.

\section{Simpulan}

Setelah dilakukan pengujian hipotesis, maka simpulan yang dapat diambil adalah: pertama, rasio keuangan secara simultan memiliki kontribusi dalam mengelompokkan perusahaan kategori financial distress dan non financial distress pada industri manufaktur di BEJ dengan menggunakan analisis diskriminan setelah dilakukan pengujian teruji kebenarannya, kedua bahwa terdapat perbedaan rasio keuangan pada industri manufaktur di BEJ dengan menggunakan analisis diskriminan, setelah dilakukan pengujian tidak sepenuhnya teruji kebenarannya. Hal tersebut disebabkan tidak semua variabel memiliki P-value lebih kecil dari 0,05. Hasil pengujian menghasilkan Leave-one-out Classification untuk melakukan cross validation, memiliki tingkat keakuratan fungsi diskriminan yang diperoleh untuk cross-validated grouped adalah di atas $90 \%$ dan tergolong akurat. Oleh karena itu bagi investor perlu mempertimbangkan variabel-variabel yang dimasukkan dalam model dalam melakukan pertimbangan investasi, terutama variabel yang memiliki discriminating power.

\section{Daftar Pustaka}

Dempsey, S. J., Harrison, D. M., \& Sheng, H. (2015). Core earnings uncertainty, dividend change announcements and the reduction of covariance component risks. Journal of Business Finance \& Accounting, 42(9-10), 1075-1120.

Garcia-Appendini, E. (2018). Financial distress and competitors' investment. Journal of Corporate Finance, 51, 182-209. 
Hillier, D., Ross, S., Westerfield, R., Jaffe, J., \& Jordan, B. (2013). Corporate finance (Issue 2nd Eu). McGraw Hill.

Opler, T. C., \& Titman, S. (1994). Financial distress and corporate performance. The Journal of Finance, 49(3), 1015-1040.

Van Horne, J. C., \& Wachowicz, J. M. (2005). Fundamentals of financial management. Pearson Education. 